\title{
IMPACT OF HARMONISATION ON DISTRIBUTION OF VAT IN THE CZECH REPUBLIC
}

\author{
Barbora Slintáková, Stanislav Klazar*
}

\begin{abstract}
:
The aim of this paper is to analyse progressivity of value added tax in the Czech Republic under the framework of both annual incidence and lifetime incidence. Moreover, impact of the harmonisation of VAT rates connected with the accession of the Czech Republic to the EU on the income distribution is examined. The burden table serves to show the distribution of the VAT burden among households by income categories; the generalised entropy measures and the Gini coefficient are used for measurement of inequality of income. Results show that the Czech VAT is regressive when annual income is analysed while the lifetime income analysis indicated that VAT is progressive. Furthermore, the results suggest that the distribution of income (annual as well as lifetime) after taxation was more equal before the harmonisation, and that impact of the changes in VAT rates in 2004 was likely larger on the lower-income households.
\end{abstract}

Keywords: value added tax, tax incidence, progressivity, redistributive effect, inequality measures, tax harmonisation

JEL Classification: H22, H23

\section{Introduction}

Our research should be a contribution to incidence analysis and measurement of global progressivity of value added tax (VAT hereafter) levied on Czech households. There is a number of studies on incidence of excise taxes but it seems that incidence and progressivity of VAT had not been for a long time a subject of rigorous research in the Czech Republic. Redistributional effect of VAT for 1994 and 1997 using Gini coefficient was analysed for example by Piotrowska (2001) or the progressivity of VAT on coffee and telecommunications in 2002 was measured by Kujová, Dvořáčková and Považská (2004), but Slavomíra Svátková's research project was the first one focused

\footnotetext{
* Barbora Slintáková, Stanislav Klazar, Univerzity of Economics, Prague (barbora@vse.cz; klazar@ vse.cz). This paper has been written as a part of the research project Public Expenditure in Postsocialist Member States of the European Union (No 402/09/0283) financially supported by the Czech Science Foundation. We wish to thank Dr. Jaromír Kalmus for processing of the input data, Martin Zelený, Ph.D. for consultation concerning the Household Budget Survey data and the PEP referees for their useful comments.
} 
on incidence of the Czech VAT in period 1993-2005 comprehensively. ${ }^{1}$ This article draws on outputs of this research and presents new results.

Common belief is that a broad based consumption tax is regressive, i. e. relatively more is paid by low-income groups of population because poor people spend a greater share of their income on consumption than rich people. That is true if annual income is considered as a potential to consume or as a measure of a taxpayer's well-being and if we assume a greater propensity to consume for poor people. However, there is both theoretical and empirical evidence that the consumption taxes could be proportional or even progressive. Such a conclusion is inferred from results of a lifetime incidence analysis when lifetime income instead of annual income is used to measure the taxpayer's well-being for purpose of analysing of tax progressivity. It is more realistic assumption that today savings will be spent on taxable goods and services in the future, hence it is legitimate to be interested also in a long-term incidence of VAT. In our paper we use both approaches to the tax incidence and we provide both short and long-term sights on the progressivity of VAT.

Progressivity of VAT apparently depends on provisions implementing the system of VAT codified in the law: especially differentiation of rates (including existence of exemption from taxation) can have a significant effect on the progressivity of VAT. For example, Caspersen and Metcalf (1993) found that 5\% VAT in the USA would be more progressive if food, housing, and health expenditures were exempted from the tax. To examine impact of various VAT rates schemes on the tax progressivity we took advantage of a special opportunity, which the harmonisation of the Czech VAT legislation with European Community VAT Directives offered to us, and compare progressivity of VAT before and after the harmonisation.

The Czech Republic introduced VAT in 1993. Although the initial legislation respected principles of functioning of VAT common in the EU Member States, the Czech VAT legislation has been brought (almost) fully in line with the Sixth VAT Directive in 2004 when the new VAT Act became effective on May $1^{\text {st }}$, the day when the Czech Republic became an EU Member State. ${ }^{2}$ However, already in the period between January $1^{\text {st }} 1993$ and May $1^{\text {st }} 2004$ a gradual alignment of the Czech legislation with the Sixth VAT Directive rules can be observed in a number of amendments which adapted the initial VAT Act.

The harmonisation process included also significant changes in the VAT rates. Two kinds of these changes can be considered. First, changes in level of the rates: the standard rate was reduced twice since the introduction of VAT in 1993: from $23 \%$ to $22 \%$ on January $1^{\text {st }} 1995$ and from $22 \%$ to $19 \%$ on May $1^{\text {st }} 2004$. Level of the reduced rate was not changed in that period. Second, changes in application of the rates, i. $e$. a switch between the reduced and standard rates or vice versa at certain goods and services (similarly, a switch between the exemption and the reduced or standard rates). ${ }^{3}$

1 It was the research project No. 402/04/1069 Analysis of Consumption Taxes Burden in the Czech Republic which was supported by the Czech Science Foundation. More details see in Svátkova et al. (2007).

2 The Sixth VAT Directive (Directive 77/388/EEC) was recast by the Council Directive 2006/112/EC in November 2006.

3 Details about development of the harmonisation of Czech VAT with the EU Directives, including details about changes in the rates see in Svátkova et al. (2007). 
Our aim is to analyse effects of the changes in the VAT rates, which are related to the accession to the EU, on progressivity of VAT borne by Czech households. It is plausible to presume that not all the changes in the VAT rates, which occurred before the entry of the Czech Republic to the EU or on the date of the entry, were "claimed" by the Sixth VAT Directive $(e . g$. increase in the rate for collection of domestic waste which was listed in the Annex H). It is possible even to hypothesise that the real reason for increase in the rate in certain cases was to augment public revenue. However in our research we do not distinguish between the changes in the rates "claimed" by the Sixth VAT Directive and the changes carried out with another purpose but justified by necessity to align the Czech VAT legislation with the EU VAT Directive. We simply presuppose that all the changes in the VAT rates were associated, directly or indirectly, with the access to the EU.

The paper proceeds as follows. In the next section we describe a micro-simulation model used to estimate Czech households' VAT liabilities. A proxy measure for lifetime income is constructed in the third section. Methods and results of the progressivity analysis are presented in the fourth section. The final section concludes the paper.

\section{Estimating VAT Liability of Czech Households}

VAT liability of each Czech household was estimated using a micro-simulation model. ${ }^{4}$ The micro-simulation model approach was preferred because individual data provided by the model were more appropriate for construction of a distributional table or calculations of inequality measures we performed (in Chapter 4).

The model was designed especially for work with the Household Budget Survey data provided by the Czech Statistical Office. This is the best available database providing information on income and expenditures of more than 3,000 Czech households. Moreover, it provides detailed household level data on consumption patterns as well as some descriptive data on household characteristics. ${ }^{5}$

Because we used data from the Household Budget Survey a household as the unit for our analysis was chosen. From consumption behaviour perspective it is a good choice because major decisions are typically made at the household level. A household is an appropriate unit of analysis when the annual approach to incidence analysis is used because well-being of a household's member depends not simply on his or her own income, but rather on income of the entire household. However, use of a household as the unit of analysis is questionable when incidence is analysed in the lifetime framework because it is not easy to think about the lifetime of a household, composition of which may vary over time.

The micro-simulation model is based on a following assumption: it is presumed that VAT is passed forward to and borne by final consumers, $i$. $e$. VAT is presumably

4 Methodology for the estimating of a household's tax liability is an outcome of the research project - see the footnote No. 1. All the computations with the Household Budget Survey data were done in the Czech Statistical Office using formulas specially developed on the basis of the model described.

5 Households in the Household Budget Survey are selected by the non-probability quota sampling technique. The sample is not strictly representative; the way of creation of the sample thus puts limitations on drawing general conclusions from our analysis. 
fully reflected in consumer prices. ${ }^{6}$ In addition, it was assumed that households do shopping only at taxable persons. Then a pragmatic cash-flow approach to determine a household's VAT liability $\left(\mathbf{T}_{\mathbf{i}}\right)$ could be taken: the tax liability is a cash tax payment made by a household during a year and in the model is calculated as follows:

$$
\mathrm{T}_{\mathrm{i}}=\sum_{n=1}^{N} S C I_{n, i} * t_{n} /\left(t_{n}+100\right)
$$

where $\mathbf{S C I}_{\mathbf{n}}$ means money expenditures on a statistical consumption item $^{7} \mathbf{n}$ and $\mathbf{t}_{\mathbf{n}}$ (in \%) is a statutory tax rate assigned to the statistical consumption item $\mathbf{n}$ (as the base, used for the tax liability calculation, is a price including VAT the tax rate was converted accordingly in the calculation).

The statistical consumption item is the lowest, and the most detailed (countryspecific) level of the consumption expenditures classification CZ-COICOP used by the Household Budget Survey. ${ }^{8}$ Each single product bought by a household is included into a particular statistical consumption item which is defined by a list of goods or services which are joined together by purpose of use. There are more than 200 items in the classification.

The model links the statistical consumption items reported by a household to relevant VAT rates in order to calculate the VAT liability for each household in the survey. An advantage of the model is that it facilitates to get the VAT liability for each household as exact as possible under conditions of the VAT rates differentiation according to kinds of goods and services. Moreover, the VAT rates file, which is supplied as exogenous set of variables to the model, may vary in structure according to the legislative state for a given period which is analysed. It is easy to modify the VAT rates file if legislative changes occur or if changes in the rates are planned - then the model can serve to simulate a possible impact of the changes. ${ }^{9}$

A crucial task was to assign a correct VAT rate to each statistical consumption item. We tried to link the rates according to the VAT Act to goods and services classified according to the CZ-COICOP as exactly as possible despite the fact that the classification of goods and services used in tax legislation is different from the one used in Household Budget Survey. Pure standard or reduced rate (or zero rate in case

6 This strong assumption is usually used in analyses like this. VAT is fully reflected in consumer prices if and only if there is no substitution effect. We supposed minimal substitution effects between consumption of different products because all the substitutes were taxed equally. We were also convinced that there was very weak substitution effect between consumption and savings in a short-time period.

7 "Statisticky znak" in Czech.

8 Household money expenditures on consumption (except expenditures on building or reconstruction of houses and dwellings and costs associated to household own farming production which are classified as non-consumption expenditures) are classified according to the Czech version of Classification of Individual Consumption by Purpose (CZ-COICOP) in the Household Budget Survey. (Besides the consumption and the non-consumption expenditures total household expenditures include taxes and social insurance contributions paid.)

9 Impact of several scenarios of changes in the VAT rates on the VAT progressivity was simulated see results in (Svátková et al., 2007). 
of goods and services exempted from VAT without the right to deduct or case of goods and services which are not subject to VAT) was assigned to statistical consumption items which consist of commodities taxed uniformly across the item. However it was necessary to calculate average rates for statistical consumption items which include goods or services taxed at different rates (or exempted from the tax).

Since we sought to reveal a change in progressivity of VAT after the accession of the Czech Republic to the EU or the VAT harmonisation, the tax liabilities were computed for two periods. The year 2003 was determined as a period before the harmonisation, though important changes in VAT rates, which could be labelled as "related to the harmonisation", occurred between 1993 and 2003. The respective tax liability was computed using statistical data collected for the year 2003 and VAT rates effective on December $31^{\text {st }}$ 2003. It was decided that the year 2005 would be a period after the harmonisation; the respective tax liability was calculated with data for the year 2005 and VAT rates effective on January $1^{\text {st }} 2005$ because they embrace crucial changes related to the harmonisation from 2004, i. e. changes in VAT rates occurred on January $1^{\text {st }}$ and on May $1^{\text {st }}$, and because no additional significant changes occurred during 2005. ${ }^{10}$ Moreover, changes in consumption behaviour of Czech households induced by the 2004 VAT rates changes could manifest themselves in size and structure of the 2005 consumption expenditures. ${ }^{11}$

\section{Proxy Measure for Lifetime Income}

The tax incidence analysis is usually based on annual income data. The most apparent reason is that the annual data are easily available, for example the Household Budget Survey in the Czech Republic. However, literature provides both theoretical and empirical arguments in favour of use also data on lifetime (permanent) income. From the lifetime incidence analysis results, which show that consumption taxation is not as regressive as the annual incidence analysis results show (see $e$. g. Fullerton and Rogers, 1991; Caspersen and Metcalf, 1993; or Metcalf, 1994), we can infer a considerable argument in favour of taxation of consumption which could be more efficient than taxation of income. The purpose of the lifetime incidence analysis is accented for example by Fullerton and Rogers (1995) or Metcalf and Fullerton (2002); the lifetime incidence analysis can be in particular suitable supplement to the annual data based analysis.

Interest in measuring the lifetime incidence of consumption taxes is supported by the Friedman's permanent income hypothesis which states that people make consumption decisions on the basis of permanent (or lifetime average) income. The lifetime incidence approach operates from the assumption that consumption is

10 Since the Household Budget Survey data are not panel data, results could be biased because the households in 2003 were not strictly the same like the households in 2005 . However, the migrating of households is approximately $20 \%$. Moreover the households were selected for the survey the same way in both years. That is why we are convinced that the bias is minimal and our conclusions are correct / sustainable.

11 We did not suppose the Pigou's announcement effects because a short-term character of goods and services demanded by households makes it almost impossible. The question is how important this effect would be on a firm level. 
relatively smooth over the life-cycle, $i . e$. temporary fluctuations in income should not lead to large changes in current consumption (people tend to maintain their past level of consumption over time in spite of changes in their current income caused by temporary bad conditions, e. $g$. illness, unemployment or retirement).

Lifetime income can be measured in one of two ways: as the present discounted value of earned income and bequests (gifts) received or as the present discounted value of consumption and bequests given. Since actual data on lifetime income or consumption of Czech households are absent the challenge of the lifetime approach is to estimate lifetime income. In our analysis we followed the approach applied in (Poterba, 1989), (Caspersen and Metcalf, 1993) or (Metcalf, 1994) when current consumption serves as a proxy for the present discounted value of consumption.

Caspersen and Metcalf (1993) or Metcalf (1994) defined the current consumption as total expenditures less new vehicle purchases, housing costs for homeowners, and contributions for pension and life insurance and adjusted by including imputed values for rents and automobiles in order to take into account housing costs for homeowners and purchases of vehicles. (Feenberg, Mitrusi and Poterba, 1997, choose another way - they excluded imputed rent while including the value of new owner-occupied homes at time of purchase.)

We utilised the Household Budget Survey data on current consumption expenditures classified according to the CZ-COICOP. However, we neither excluded purchases of vehicles nor we adjusted the data in order to take into account these purchases as Caspersen and Metcalf (1993) or Metcalf (1994) did. On the other hand, we did not need to exclude expenditures on purchases of houses because the CZ-COICOP do not include them. Unfortunately, the survey does not report imputed rental so that we could not adjust current consumption expenditures of homeowners. Finally, our consumption expenditures data are free of the social insurance contributions because they are not considered as consumption expenditures according to the CZ-COICOP classification.

On the basis of Metcalf's findings we ignored bequests. Metcalf (1994) found out that excluding of bequests from construction of the lifetime income proxy did not affect results of the distributional analysis significantly. Moreover, the author refers to the analysis of Menchik and David who suggest that ignoring of bequests would only overstate the progressivity of a consumption tax for the top of the income distribution and underestimate the progressivity over the rest of distribution. ${ }^{12}$

\section{Measurement of VAT Progressivity}

\subsection{Methodology}

First we created a distributional table which simply shows how the burden of the VAT is divided among households which vary in income, and provides information about the pattern of increase or decrease in the tax burden by income category. We defined the VAT burden $\left(\mathbf{B}_{\mathbf{i}}\right)$ as a ratio of the household tax liability $\left(\mathbf{T}_{\mathbf{i}}\right)$ to household well-being $\left(\mathbf{W}_{\mathrm{i}}\right)$ :

12 An original source "Menchik, P., David, M. (1982) The Incidence of a Lifetime Consumption Tax. National Tax Journal, 35 (2), 189-203" is cited by Metcalf (1994). 


$$
B_{i}=T_{i} / W_{i}
$$

Household's well-being is measured by both annual and lifetime income. The annual income includes money and natural income before taxation by a personal income tax and imposition of social insurance contributions, $i$. $e$. gross income received by a household. The lifetime income is represented by the consumption expenditures, as defined in Chapter 3, including VAT, i. e. gross expenditures spent by a household.

Since our VAT burden measure is in fact an average tax rate, the tax can be considered as progressive if the average tax rate increases with income, and the tax can be characterised as regressive if the average tax rate decreases with income.

Furthermore, to analyse impact of VAT on income inequality we employed often used inequality measures such as the class of generalised entropy measures (GE) and the Gini coefficient. ${ }^{13}$ The general formula of the GE inequality measures is:

$$
G E(\alpha)=\frac{1}{\alpha^{2}-\alpha}\left[\frac{1}{n} \sum_{i=1}^{n}\left(\frac{y_{i}}{\bar{y}}\right)^{\alpha}-1\right]
$$

where $\mathbf{n}$ is the number of individual households in the sample, $\mathbf{y}_{\mathbf{i}}$ is income of individual household $\mathbf{i}$, and $\bar{y}=(1 / \mathrm{n}) \sum$ yi. The value of $\operatorname{GE}(\alpha)$ ranges from 0 to $\infty$. Zero means an equal income distribution. The higher the value of the $\operatorname{GE}(\alpha)$ the more inequal income distribution is.

The parameter $\alpha$ represents the weight given to inequality in different tails of income distribution. By changing $\alpha$, which can take any real value, we can put emphasis on lower or upper tail of income distribution in order to examine effects of the tax on income inequality in different income groups. ${ }^{14}$

The composed Gini coefficient measured on population $\mathrm{P}$ is:

$$
G=\frac{\sum_{i=1}^{n} \sum_{r=1}^{n}\left|y_{i}-y_{r}\right|}{2 n^{2} \bar{y}}
$$

where $\mathrm{n}$ is the number of individual households in the sample, yi is income of individual household i, yr is income of individual household $\mathrm{r}, \bar{y}=(1 / \mathrm{n}) \sum \mathrm{yi}$. The value of the Gini coefficient ranges from 0 to 1 . Zero means an equal income distribution, 1 means unequal income distribution.

On the basis of the Gini coefficients measuring the inequality of income before and after taxation the Thin-Musgrave index of effective progressivity (EP) is constructed (see Coronado, Fullerton and Glass, 2000) as follows:

$$
E P=\left(1-G_{\text {affer }}\right) /\left(1-G_{\text {before }}\right)
$$

13 For a brief summary how to measure inequality of income see $e$. g. Litchfield (1999). Which measure to prefer is explained $e . g$. by Zandvakili and Mills (2000).

14 Our choice of $\alpha$ follows the recommendation of Litchfield (1999). If $\alpha=1$ (the so called Theil index) then equal weights are assigned both to the lower and upper tails of income distribution. With $\alpha=$ 0,2 the measure is more sensitive to changes in the lower tail of distribution, with $\alpha=2$ the measure is more sensitive to changes in the upper one. 
where $\mathbf{G}_{\text {after }}$ is the Gini coefficient for income distribution after taxation, and $\mathbf{G}_{\text {before }}$ is the Gini coefficient for income distribution before taxation. Progressive effect of a tax, $i . e$. income is more equally distributed after taxation, is indicated if value of EP exceeds 1 . Regressive effect of a tax, $i$. $e$. income is more unequally distributed after taxation, is signalled if value of EP is less than 1.

Impact of VAT on the income inequality is also expressed using index of the GE inequality measures before and after taxation. However, in contrast to the Gini coefficient, VAT is progressive if the GE inequality measures index is less than 1 (i.e. VAT reduces the inequality of income), and VAT is regressive if the index exceeds 1 (i. e. VAT raises the income inequality).

Since it is not correct to assess position of a household as rich or poor according to its total well-being regardless of number of its members or their needs, it was decided that a household as a whole would be represented by its "one-member household equivalent" in the measurement of income inequality, and in allocation of households into deciles in the distributional table. Therefore households heterogeneous in a number of members were transformed into quasi-homogeneous sample using a weighting scheme to calculate an average well-being of a household. The average was calculated by dividing a household's total well-being by a number of so called consumption units. $^{15}$

\subsection{Results and Comments}

The third through twelfth columns of Table 1 show the average VAT burden borne by households in each income category. To assess the annual incidence the annual gross income is used to divide households into deciles and to calculate the VAT burden. The lifetime income $(i$. e. consumption expenditures) is used in the VAT burden calculation and for the allocation of households into the deciles to measure the lifetime incidence. ${ }^{16}$ Moreover, the distribution of the VAT burden before (year 2003) and after (year 2005) the VAT harmonisation can be compared in Table 1. (For a better visualisation of the tax burden distribution, see the Figure 1.)

Table 1

Distribution of the VAT Burden in the Czech Republic before and after the VAT Harmonisation (in \%), Annual and Lifetime Incidence

\begin{tabular}{|l|r|r|r|r|r|r|r|r|r|r|r|}
\hline & Decile & First & Second & Third & Fourth & Fifth & Sixth & Seventh & Eighth & Ninth & Last \\
\hline Incidence & & & & & & & & & & & \\
\hline \multirow{2}{*}{ Lifetime } & 2003 & 10,38 & 10,78 & 10,53 & 10,83 & 10,88 & 11,04 & 11,31 & 11,35 & 11,62 & 12,61 \\
\cline { 2 - 13 } & 2005 & 10,74 & 10,81 & 11,16 & 11,13 & 11,44 & 11,50 & 11,40 & 11,88 & 11,73 & 12,85 \\
\hline \multirow{2}{*}{ Annual } & 2003 & 8,82 & 8,53 & 8,57 & 8,70 & 8,27 & 8,04 & 8,10 & 8,06 & 7,37 & 7,09 \\
\cline { 2 - 11 } & 2005 & 9,19 & 8,71 & 8,66 & 8,68 & 8,25 & 8,08 & 7,97 & 8,00 & 7,30 & 7,03 \\
\hline
\end{tabular}

15 This weighting scheme is used by the Czech Statistical Office. The number of the consumption units is calculated as follows: $\mathrm{CU}=1+0,5$ (number of children) $+0,7$ (number of members -1 - number of children).

16 For the ranking of households equivalent income was used. The first decile includes app. 300 of the poorest households, the last decile app. 300 of the richest ones. 
Figure 1

Distribution of the VAT Burden in the Czech Republic before and after the VAT Harmonisation (in \%), Annual and Lifetime Incidence

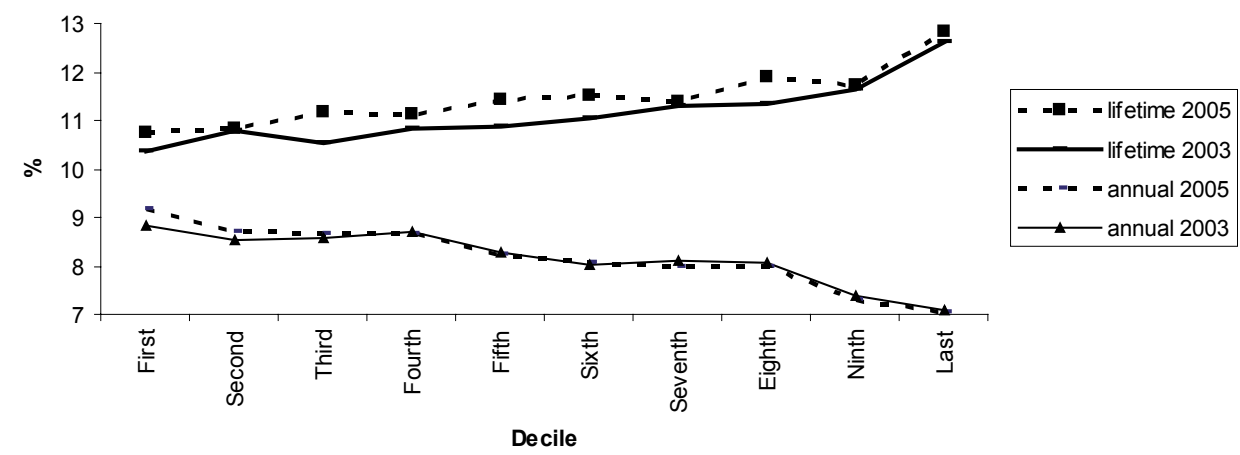

From comparison of tax burdens, when they are computed as the tax liability to consumption expenditures ratio, before and after the harmonisation it is evident that the burden of the VAT increased after the harmonisation. However, the annual-based analysis shows that the VAT burden increased after the harmonisation only in the first three and in the sixth deciles.

The next important information, the distribution table provides, is that the average tax burden, when calculating with the annual income, is decreasing with income although not over the entire range. The VAT can be thus considered as regressive. However, looking at the lifetime incidence the average tax burden is increasing with income - again this function profile is "disturbed" in some deciles. Then we can call the VAT in the Czech Republic progressive tax.

To analyse the global progressivity of VAT we measured and compared inequality of pre-tax income and post-tax income. The gross income $(\mathbf{Y})$ or the gross expenditures (C) - representing the lifetime income - as defined in Chapter 4.1 served as the pre-tax income (Y_before or $\mathbf{C} \_$before) in calculations. The post-tax income (i. e. Y_after or C_after) was defined as the pre-tax income less the tax liability (see Chapter 2).

Table 2 shows inequality of households' well-being before and after imposition of VAT in 2003 and 2005 measured by the Gini coefficient. To summarise the redistributive effect of VAT the Thin-Musgrave index of effective progressivity was calculated.

Table 2

The Gini Coefficients and Thin-Musgrave Indices of Effective Progressivity for Years 2003 and 2005

\begin{tabular}{|l|c|c|c|c|}
\hline & Y_before_2003 & Y_after_2003 & C_before_2003 & C_after_2003 \\
\hline Gini & 0,2168 & 0,2206 & 0,1976 & 0,1945 \\
\hline EP & & 0,9951 & & 1,0039 \\
\hline & Y_before_2005 & Y_after_2005 & C_before_2005 & C_after_2005 \\
\hline Gini & 0,2315 & 0,2357 & 0,2085 & 0,2054 \\
\hline EP & & 0,9945 & & 1,0038 \\
\hline
\end{tabular}


As the Gini coefficient rises the annual income becomes more unequal after imposition of VAT. The Thin-Musgrave index of effective progressivity says that VAT is regressive when the inequality of annual income is measured. On the contrary, we see decline in the Gini coefficient and the Thin-Musgrave index exceeding 1 for distribution of lifetime income, that is to say VAT is progressive when analysing the lifetime income inequality. In addition, the regressive effect of VAT appears to be stronger in 2005 than in 2003, and the progressive effect of VAT seems to be stronger in 2003 than in 2005.

In Table 3 we show summarised results of measuring of the income inequality before and after taxation in the years 2003 and 2005 using the GE inequality measures with different $\alpha$. The indices express a change between the distribution before taxation and the distribution after taxation.

Table 3

The GE Inequality Measures Indices for Year 2003 and 2005

\begin{tabular}{|l|c|c|}
\hline & $\frac{\text { GE_Y_after_2003 }}{\text { GE_Y_before_2003 }}$ & $\frac{\text { GE_C_after_2003 }}{\text { GE_C_before_2003 }}$ \\
\hline $\boldsymbol{\alpha}=\mathbf{1}$ & 1,0379 & 0,9615 \\
\hline $\boldsymbol{\alpha}=\mathbf{0 , 2}$ & 1,0364 & 0,9660 \\
\hline $\boldsymbol{\alpha}=\mathbf{2}$ & 1,0426 & 0,9524 \\
\hline & $\frac{\text { GE_Y_after_2005 }}{\text { GE_Y_before_2005 }}$ & $\frac{\text { GE_C_after_2005 }}{\text { GE_C_before_2005 }}$ \\
\hline $\boldsymbol{\alpha}=\mathbf{1}$ & 1,0404 & 0,9659 \\
\hline $\boldsymbol{\alpha}=\mathbf{0 , 2}$ & 1,0385 & 0,9693 \\
\hline $\boldsymbol{\alpha}=\mathbf{2}$ & 1,0484 & 0,9583 \\
\hline
\end{tabular}

Results in Table 3 imply that VAT enhanced income inequality when annual income is analysed, but VAT reduced income inequality when lifetime income is used in the analysis. This finding is consistent with the one resulted from the Gini coefficients calculations. In comparison with the Gini coefficient the GE inequality measures are capable of locating changes in particular tails of distribution. From analysis of GE values for different $\alpha$ we infer that changes in distribution of income were more significant among rich households than in the lower tail of distribution of households. This conclusion is valid for both years.

Furthermore, we compare the distribution of (annual as well as lifetime) income after taxation in 2003 and the distribution of income after taxation in 2005. The prospective GE inequality measures indices are in Table 4. 
Table 4

The GE Inequality Measures Indices for Post-tax Income Distribution

\begin{tabular}{|l|c|c|}
\hline & $\frac{\text { GE_Y_after_2005 }}{\text { GE_Y_after_2003 }}$ & $\frac{\text { GE_C_after_2005 }}{\text { GE_C_after_2003 }}$ \\
\hline $\mathbf{\alpha = 1}$ & 1,1713 & 1,1375 \\
\hline $\mathbf{\alpha}=\mathbf{0 , 2}$ & 1,1529 & 1,1265 \\
\hline $\mathbf{\alpha}=\mathbf{2}$ & 1,2315 & 1,1671 \\
\hline
\end{tabular}

From Table 4 it seems that inequality of households' post-tax income was greater in 2005 in both approaches although rise in income inequality is smaller when lifetime approach is used. This conclusion is supported by the Gini coefficients in Table 2. ${ }^{17}$ To sum up, inequality of households' post-tax income rose after harmonisation of VAT or in other words, distribution of post-tax income among Czech households was more equal before the harmonisation.

A question is, to what extent the changes in taxation affected the difference between the 2003 VAT distribution (i. e. before the harmonisation) and the 2005 VAT distribution (i. e. after the harmonisation) - see Table 1, and the difference in the post-tax income inequality between 2003 and 2005. Karoly (1996) distinguishes two effects of taxes on post-tax income distribution: a redistributive effect of the tax legislation or the tax construction affecting directly post-tax income, and a dynamic effect of the tax on the pre-tax income which influences post-tax income distribution indirectly.

Because rates (including exemptions) are part of the tax construction the changes in the VAT burden distribution or in the progressivity of VAT between 2003 and 2005 could be consequence also of a number of differently directed changes in the VAT rates, which occurred in 2004. Significant changes in the rates were the following: a switch of the reduced rate to the standard rate (for a number of services, $e$. g. telecommunications services) effective from January $1^{\text {st }}, 2004$, and reduction in the standard tax rate (from $22 \%$ to $19 \%$ ), a switch between the reduced and the standard rates for further services (e. g. domestic waste collection, restaurants, etc.), and a switch between tax exemption and the reduced rate (e.g. for pharmaceutical products) effective from May $1^{\text {st }}, 2004$. Presupposing given consumption expenditures structures for households with different income when goods and services, whose rate switched from reduced to standard, were consumed rather by lower-income households (this holds especially for domestic waste collection and telecommunication services), and goods and services, on which the standard rate has been applied already since the VAT was adopted, were consumed rather by higher-income households (this is true for alcoholic beverages, clothing, maintenance and repair of the dwelling, furnishing, house equipment and routine house maintenance or purchase of vehicles), we suggest that the changes in VAT rates had caused that VAT burden of lower-income households became closer to VAT burden of higher-income households in 2005 (if analysed lifetime income), and that VAT burden of lower-income households grew faster than VAT burden of

17 In addition, the EP in 2005 is smaller than the EP in 2003 if analysed annual income which means that VAT in 2005 was more regressive than in 2003; the EP in 2005 is smaller than the EP in 2003 if analysed lifetime income which means that VAT in 2005 was less progressive than in 2003. 
higher-income households after the 2004 changes in the VAT rates (if analysed annual income). ${ }^{18}$

In addition, the rise in the VAT burden after the harmonisation (i. e. between 2003 and 2005 - see Table 1) can be explained by that a switch of the reduced rate to the standard rate or a switch between exemptions and the reduced rate at a number of goods and services outweighed the standard tax rate reduction (from $22 \%$ to $19 \%$ ). However, the burden did not grow unambiguously, when measured as the tax liability to income ratio - probably because the gross income grew relatively more than the VAT liability did between 2003 and 2005 in households allocated in the fourth and further deciles.

To compare redistributive effects of VAT in 2003 and 2005 correctly it is necessary to take into account also a change in distribution of the pre-tax income between 2003 and 2005. The indices of GE measures for the pre-tax income inequality in Table 5 show how inequality rose between 2003 and 2005. It is worth noting that difference between the post-tax income distributions in 2003 and 2005 (see Table 4) is bigger than the difference between the pre-tax income distributions. One reason is impact of VAT. ${ }^{19}$

Table 5

The GE Inequality Measures Indices for Pre-tax Income Distribution

\begin{tabular}{|l|c|c|}
\hline & $\begin{array}{c}\text { GE_C_before_2005 } \\
\text { GE_C_before_2003 }\end{array}$ & $\begin{array}{c}\text { GE_Y_before_2005 } \\
\text { GE_Y_before_2003 }\end{array}$ \\
\hline $\boldsymbol{\alpha}=\mathbf{1}$ & 1,1686 & 1,1323 \\
\hline $\boldsymbol{\alpha}=\mathbf{0 , 2}$ & 1,1506 & 1,1227 \\
\hline $\boldsymbol{\alpha}=\mathbf{2}$ & 1,2247 & 1,1599 \\
\hline
\end{tabular}

Unfortunately, our analysis cannot show how the rise in pre-tax income inequality is attributed to the indirect effects of the changes in VAT rates and to other factors affecting income distribution. We can only guess that the changes in VAT rates faced by households could alter their consumption behaviour or even their preferences to earn (through changes in prices of goods and services consumed).

Another interesting issue is the difference between results of annual and lifetime incidence approaches. Both the distributional table and the inequality measures suggest that the Czech VAT is progressive when using consumption as a proxy for lifetime income but it is regressive when annual income is analysed. Our findings are consistent with those of Caspersen and Metcalf (1993) or Metcalf (1994) who conducted comparison of VAT incidence when households were categorised on the basis of different well-being measures. They found out that if annual income is used

18 Source of data: "Př́ijmy, vydání a spotřeba domácností statistiky rodinných účtů za rok 2003" (2005), "I. díl - sociální skupiny, př́ijmová pásma." Tab. 3/4 "Skupiny spotřebních vydání.” ČSÚ. Available on http://www.czso.cz/csu/2004edicniplan.nsf/p/3001-04 for 2003, and http://www.czso. cz/csu/2006edicniplan.nsf/publ/3001-06-za_rok_2005,_i_dil__socialni_skupiny,_prijmova_pasma for 2005 .

19 Looking at values for different $\alpha$ in the Tables 4 and 5 we can (again) infer that there was a greater change in income distribution among rich households than among poor households. 
to measure economic well-being and rank households, VAT is regressive. However, if the current consumption as the proxy for lifetime income is used to rank households and calculate the tax burden, VAT looks proportional or progressive depending on the design scheme of the tax.

Most often mentioned - for example by Poterba (1989), Caspersen-Metcalf(1993), Metcalf (1994) or Fullerton-Rogers (1991, 1995) - sources of divergence between groupings of units of analysis (especially in the distributional table) in the annual and the lifetime incidence analyses are: evolving profile of income during a life, and volatility of income between years. These patterns can put into lower-income groups measured by annual income both the rich from the lifetime perspective (i.e. young workers just starting a career, some retirees who had earned earlier, and people who just had a bad year) and the perennially poor.

Besides fluctuations in the annual income different consumption to income ratios depending on how income is measured can be another source of the difference between the annual and lifetime incidence of the VAT. In our case it is worth stressing probable influence of a propensity to consume combined with a structure of consumption including goods and services taxed at different rates.

Since it is assumed that the entire income is consumed in the lifetime incidence approach (then the consumption to income ratio is equal 1), how much households with different income spend on goods taxed at the reduced rate (or on goods exempt from VAT) and how much on goods taxed at the standard rate is decisive to determine the incidence of VAT. In order VAT to tend towards the progressive impact, goods and services, expenditures on which represent a higher portion of total consumption expenditures of lower-income households, must be taxed at the reduced tax rate or be exempt from VAT. By examining the structure of consumption in particular deciles and tax rates applied on particular products consumed by households in the deciles we found out that Czech lower-income households consumed proportionately more food, housing - namely water supply, and public transport, on which the reduced rate was applied. On the other hand, VAT tends towards the regressive effect if on products, which are consumed to the larger extent by lower-income households, is applied the standard rate. This was applied for tobacco, footwear, operation of vehicles including fuels, and communication. Our results suggest that the tendency towards the progressive impact outweighs the tendency to the regressivity.

Illustrative is also Table 6. There are average VAT liability shares of consumption expenditures for particular income categories, when households are distributed by annual income, in Table 6. It is obvious that the higher-income households spend more on products taxed at higher rate and therefore VAT tends to the progressive effect. (Consumption expenditures cut according to VAT rates are in Table 8.)

Table 6

Share of Taxation in Consumption of Households (in \%)

\begin{tabular}{|l|c|c|c|c|c|c|c|c|c|c|}
\hline Decile & First & Second & Third & Fourth & Fifth & Sixth & Seventh & Eighth & Ninth & Last \\
\hline $\mathbf{2 0 0 3}$ & 10,15 & 10,51 & 10,74 & 10,93 & 11,29 & 11,39 & 11,42 & 11,60 & 11,45 & 11,88 \\
\hline $\mathbf{2 0 0 5}$ & 10,53 & 10,78 & 11,14 & 11,47 & 11,57 & 11,54 & 11,81 & 12,01 & 11,74 & 12,05 \\
\hline
\end{tabular}


In case of annual incidence approach the consumption expenditures to annual income ratio (which is less than 1 or equal to 1) plays a role. If the propensity to consume was constant and structure of consumption was identical over households then results of both approaches to tax incidence would be similar. However, smaller propensity to consume of higher-income households tends to make a consumption tax look more regressive when impact on distribution is measured on the annual income base. Table 7 includes (average) consumption to income ratios for households ranked to the deciles according to their annual income. It is seen that consumption constitutes a smaller part of income for the higher-income households (it holds for both years).

Table 7

Consumption to Income Ratios across Income Deciles (in \%)

\begin{tabular}{|l|c|c|c|c|c|c|c|c|c|c|}
\hline Decile & First & Second & Third & Fourth & Fifth & Sixth & Seventh & Eighth & Ninth & Last \\
\hline $\mathbf{2 0 0 3}$ & 87 & 81 & 80 & 78 & 73 & 70 & 70 & 68 & 64 & 59 \\
\hline $\mathbf{2 0 0 5}$ & 87 & 80 & 78 & 75 & 71 & 70 & 67 & 66 & 61 & 57 \\
\hline
\end{tabular}

However, significant share of expenditures on goods and services taxed at the reduced rate or exempted from the tax in the lower-income households could counter the tendency towards the regressivity generated by the propensity to consume. This does not seem to be true as Table 8 shows. Table 8 reports shares of consumption expenditures spent on goods and services taxed at different VAT rates (households are ranked according to annual income).

Table 8

Structure of Expenditures on Goods and Services Taxed at Different VAT Rates Consumed by Different Households (in \%)

\begin{tabular}{|l|l|c|c|c|c|c|c|c|c|c|c|}
\hline & Decile & First & Second & Third & Fourth & Fifth & Sixth & Seventh & Eighth & Ninth & Last \\
\hline \multirow{3}{*}{2003} & Exempt & 11 & 11 & 11 & 11 & 11 & 12 & 12 & 11 & 12 & 12 \\
\cline { 2 - 14 } & $5 \%$ & 45 & 44 & 45 & 44 & 43 & 42 & 41 & 39 & 39 & 34 \\
\cline { 2 - 14 } & $22 \%$ & 44 & 45 & 44 & 45 & 46 & 46 & 47 & 50 & 49 & 54 \\
\hline \multirow{3}{*}{2005} & Exempt & 13 & 12 & 11 & 12 & 12 & 13 & 12 & 13 & 14 & 14 \\
\cline { 2 - 13 } & $5 \%$ & 34 & 31 & 32 & 34 & 33 & 31 & 30 & 28 & 26 & 22 \\
\cline { 2 - 13 } & $19 \%$ & 53 & 57 & 57 & 54 & 55 & 56 & 58 & 59 & 60 & 64 \\
\hline
\end{tabular}

Note: Exempt means exempted from the tax, $5 \%$ is reduced rate, 22 (19) \% is standard rate.

Source: Data cited in the footnote No $18^{20}$ and the micro-simulation model (VAT rates).

20 We used the consumption expenditures distribution of the Czech Statistical Office, which is available on its website, because we did not have such data at our disposal. Since households are ranked into deciles according to net per capita income in Table 8, results deviate from those we would get if households were divided according to gross income per consumption unit (as we did in our analysis). Despite the deviations we incline to consider the consumption expenditures distribution reported in Table 8 sufficient to serve as an explanation of the rate of the progressivity of the VAT. (This note is relevant also for the explanation of the impact of the changes in the rates see above.) 
Despite the consumption of the lower-income households is biased towards goods and services taxed at the reduced rate (or exempted), the higher portion of expenditures on the less taxed goods and services does not seem significant. Moreover, it seems that the higher-income households consume slightly more products exempted from the tax. ${ }^{21}$ To sum up, according to our results of measuring of VAT progressivity we suggest that although lower-income households spend more their expenditures on goods and services taxed at reduced rate their higher consumption to annual income ratio counteracts the progressive effect of VAT and makes VAT regressive.

\section{Conclusions}

Our results showed that the Czech VAT was regressive under the annual income analysis. In contrast, the lifetime income analysis indicated that VAT was progressive. Reason underlying these divergent findings may be the following. The potential to consume can be considered in a short-time (i.e. annual) framework but also in a long-time (i. e. lifetime) horizon. Since annual income is allocated between consumption (taxed by a consumption tax) and savings, a consumption tax is regressive because lowerincome households consume more than higher-income households. In addition, even distribution of expenditures, when the poorer consume more goods and services taxed at the reduced rate and less products taxed at the standard rate than the richer, cannot diminish the effect of the propensity to consume and therefore the lower-income households pay relatively more on VAT in comparison with higher-income households. To the contrary, in the lifetime framework, when a tax is applied to all consumption, which is equal to income (ignoring bequests), the structure of the consumption, which is biased rather towards less taxed products in the lower-income households and towards more taxed products in the higher-income households, causes that VAT appears to be progressive.

Conclusion that people with a higher tax burden today do not have to be the people with the higher burden forever may favour taxation of consumption at the expense of taxation of income. Policy makers need not be afraid to enhance the consumption taxation because it can be done even with redistributive impact. Moreover, as the consumption taxation removes the double taxation of interest income a shift from the income taxation towards the consumption taxation would lead to improved economic efficiency. Nevertheless, it must be stressed that these effects may manifest themselves in a long-run time horizon which is not so popular in policy making.

Furthermore, according to our lifetime-based analysis the Czech VAT was more progressive in 2003 which may mean that after the harmonisation process VAT burden of the lower-income households came closer to VAT burden of the higher-income households. (The reader should be aware that not all the changes in VAT construction were actually required by the harmonisation process.) Viewed in the annual framework the Czech VAT was more regressive after the alignment to the Sixth VAT Directive. These findings suggest that impact of the changes in VAT rates was more likely larger on

21 Change in the expenditures proportions by the rates were caused by shifts in consumption patterns and changes in VAT rates between 2003 and 2005. For example apparent reduction of the expenditures on products taxed at the reduced rate in 2005 might be a consequence of a switch of the reduced to the standard rate for certain goods and services in 2004. 
the lower-income households. That could be explained by a switch between the reduced and standard rates which must have touched rather goods and services consumed by the lower-income households. However, the changes in the VAT rates may not be a single factor influencing the rate of progressivity of VAT after the harmonisation. Changes in the pre-tax income distribution and in structure of households' consumption might also play role.

Our research revealed that the design of VAT, including arrangement of rates, can affect the rate of the progressivity and thus it can be a tool of the redistribution policy. Application a certain rate on goods or service selected on the basis of the distribution of their consumption across income categories can increase or decrease the rate of the progressivity of VAT.

\section{References}

Bradford, D. F. (1995), Distributional Analysis of Tax Policy. Washington, DC: The AEI Press.

Caspersen, E., Metcalf, G.E. (1993), "Is a Value Added Tax Progressive? Annual versus Lifetime Incidence Measures". NBER Working Paper No. 4387. Available on: http://www.nber.org/papers/ w4387. [19 June 2006].

Coronado, J. L., Fullerton, D., Glass, T. (2000), “The Progressivity of Social Security”. NBER Working Paper No. 7520. Available on: http://www.nber.org/papers/w7520. [7 January 2004].

Feenberg D. R., Mitrusi A. W., Poterba, J. M. (1997), "Distributional Effects of Adopting a National Retail Sales Tax". NBER Working Paper No. 5885. Available on: http://www.nber.org/papers/ w5885. [19 June 2006].

Fernandez-Corugedo, E. (2004), Consumption Theory. Handbooks in Central Banking No 23. Bank of England, Centre for Central Banking Studies. Available on: http://www.bankofengland.co.uk/ education/ccbs/handbooks/pdf/ccbshb23.pdf. [19 June 2006].

Fullerton, D., Rogers, D. L. (1991), "Lifetime vs. Annual Perspectives on Tax Incidence". NBER Working Paper No. 3750. Available on: http://www.nber.org/papers/w3750. [10 January 2004].

Fullerton, D., Rogers, D. L. (1995), "Distributional Effects on a Lifetime Basis" in Bradford, D. F., ed., Distributional Analysis of Tax Policy. Washington, DC: The AEI Press, pp. 262-294.

Hassett, K. A., Mathur, A., Metcalf, G. E. (2007) "The Incidence of a U. S. Carbon Tax: a Lifetime and Regional Analysis”. NBER Working Paper No. 13554. Available on: http://www.nber.org/papers/ w13554. [9 January 2008].

Jenkins, G. P., Jenkins, H., Kuo, C. (2006) “Is the Value Added Tax Naturally Progressive?" (April 18, 2006. Available on: http://papers.ssrn.com/sol3/papers.cfm?abstract_id=897677. [9 January 2008].

Karoly, L. A. (1996), "Trends in Income Inequality: the Impact of, and Implications for, Tax Policy" in Slemrod, J., ed., Tax Progressivity and Income Inequality. Cambridge University Press, pp. 95-129.

Kujová, I., Dvořáčková, J., Považská, P. (2004) “Incidence daně z přidané hodnoty v České republice a její změny po harmonizaci s Evropskou unií". Masarykova univerzita v Brně, Ekonomickosprávní fakulta. a seminar work.

Litchfield, J. A. (1999), "Inequality: Methods and Tools". Text for the World Bank. Available on: http:// siteresources.worldbank.org/INTPGI/Resources/Inequality/litchfie.pdf. [10 June 2004].

Mathis, A. (2004), "VAT Indicators". Office for Official Publications of the European Communities. Taxation Papers, Working Paper No. 2. Available on: http://ec.europa.eu/taxation_customs/ resources/documents/vat_indicators.pdf. [19 June 2006].

Metcalf, G. E. (1994), "Lifecycle vs. Annual Perspectives on the Incidence of a Value Added Tax". NBER Working Paper No. 4619. Available on: http://www.nber.org/papers/w4619. [19 June 2006]. 
Metcalf, G. E. (1998), "A Distributional Analysis of an Environmental Tax Shift”. NBER Working Paper No. 6546. Available on: http://www.nber.org/papers/w6546. [19 June 2006].

Metcalf, G. E., Fullerton, D. (2002), "The Distribution of Tax Burdens: An Introduction". NBER Working Paper No. 8978. Available on: http://www.nber.org/papers/w8978. [19 June 2006].

Musgrave, R. A., Musgrave, P. B. (1994), Veřejné finance $v$ teorii a praxi. Praha: Management Press.

Mussard, S., Seyte, F., Terraza, M. (2003), "Decomposition of Gini and the Generalized Entropy Inequality Measures". Economics Bulletin, 4(7), pp. 1-6.

Piotrowska, M. (2001) "Marginal Changes in Prices and Income Inequality in Central European Countries: the Progressivity of Indirect Taxes". Paper presented at the $57^{\text {th }}$ Congress of IIPF in Linz.

Poterba, J. M. (1989), "Lifetime Incidence and the Distributional Burden of Excise Taxes". NBER Working Paper No. 2833. Available on: http://www.nber.org/papers/w2833. [19 June 2004].

Svátková, S., Klazar, S., Slintáková, B., Zelený, M. (2007), Zatižení spotřebního koše domácností daněmi ze spotreby $v$ České republice. Praha: Eurolex Bohemia.

Zandvakili, S., Mills, J. A. (2000), "The Distributional Implications of Tax and Transfer Programs in US". Paper presented at the IIPF Congress in Seville. 